\title{
Modelling the Innovative Competitiveness of an Enterprise with a Change in Investment Provision
}

\author{
INNA IRTYSHCHEVA ${ }^{1}$, ANDRII SUKHOSTAVETS ${ }^{2}$, VOLODYMYR FALOVYCH ${ }^{3}$, \\ OLEKSANDR KOVBASA ${ }^{4}$, OLEKSANDR LIASHOK ${ }^{5}$, ELEONORA KOLESNIK ${ }^{6}$ \\ ${ }^{1}$ Department of Management, ADMIRAL MAKAROV NATIONAL UNIVERSITY OF SHIPBUILDING, UKRAINE. \\ 2,4 Department of Economics and Entrepreneurship, SUMY NATIONAL AGRARIAN UNIVERSITY, UKRAINE. \\ ${ }^{3}$ Department of Industrial Marketing, TERNOPIL IVAN PULUJ NATIONAL TECHNICAL UNIVERSITY, UKRAINE. \\ ${ }^{5}$ Department of Management and Financial and Economic Security, DONETSK NATIONAL TECHNICAL \\ UNIVERSITY, UKRAINE. E-mail: mart t0@ukr.net \\ ${ }^{6}$ Department of Economics, CLASSICAL PRIVATE UNIVERSITY, UKRAINE.
}

\begin{abstract}
The article deals with modern problems of modelling the innovative competitiveness of an enterprise operating in the real sector of the economy. An attempt has been made to form a tool that allows analysts, based on the given parameters, to form a model that will enable one to assess certain innovative competitive advantages visually. The competitive environment of the modern market predetermines special requirements for the process of effective use of the investment and innovation potential of an enterprise, which is why the article considers an approach to modelling the competitiveness of an enterprise from these two positions.

The approach proposed by the authors is designed to form a feeling of completeness and completeness of the mathematical model, not complicated by additional data, but at the same time giving a complete picture of the real state of affairs of the enterprise from the standpoint of competition in the market. The mathematical and economic model is based on several critical aspects designed to reflect the competitive potential of an enterprise in terms of innovation processes.

The formed model of innovative competitiveness takes into account modern economic realities and emphasises the changeable feature of the investment resources available to enterprise management. From accessibility for use, the investment support of innovative activity can be modelled as a variable that carries the nature of uncertainty.
\end{abstract}

Keywords: innovative competitiveness, investment attractiveness, investment support, mathematical model

JEL Classification: 012, C54, D78, D2 


\section{Introduction.}

The current state of the world economic system is characterised by a high level of economic activity, manifested in various forms and is characterised by a high dynamism of transformations affecting the socio-economic development of society. Competitive processes in multiple spheres of social and economic life play one of the critical roles in the behaviour of market participants and the formation of its structure (Zakharkin et al., 2019).

Modern trends show that innovation and innovation are both a key factor in economic development and an element of a system of parameters that provide competitive advantages for an enterprise (Prokopenko et al., 2020). It is worth noting that a fundamental issue of the effectiveness of innovation is sufficient and timely investment in the innovation potential of the enterprise. To understand the causes and factors affecting competitive processes is essential to be able to experimentally model and analyse those parameters that make up the innovative advantage of an enterprise (Koval et al., 2020).

\section{Theoretical foundations of the formation of the competitive advantages of an enterprise, based on innovative development.}

Speaking about the competitiveness of an enterprise from an innovation point of view, the innovative environment acts as the basis for the competitive development of the subjects of the real sector of the market, which must be considered as a special institutional basis that forms the necessary incentives and ensures the formation of proper motivation for these enterprises to intensive development and balanced economic growth through the cognition of economic activity (Sheng-Yi, 1990; Akinlo et al., 2020).

The competitiveness of an enterprise should be considered not only from the position of a theoretical category but also as a quantitative measure of the effectiveness of its functioning. At the same time, the innovative component, against the background of other aspects of competitiveness, acquires its special meaning. Innovative advantages for an enterprise are formed under the influence of several key factors, which can be combined into three aspects - social, technological and economical, the scheme of their formation and impact on competitiveness is presented in Fig. 1.

Innovation, as part of the modern entrepreneurial process and the basis for competitive enhancement, must be protected by factors that potentially prevent competitors from replicating their advantages. Competitive advantages, in their essence, are a set of distinctive properties of an object that create certain economic benefits or represent a certain value.

In the approach to defining the essence of innovative competitive advantage, one should distinguish between the market and resource vectors. In the case of the market vector, the sources of creation of competitive advantages will be the factors of the external environment, in the case of the resource vector, the factors of the internal environment (Abdollahbeigi \& Salehi, 2018; Garifova, 2018; Soloveichik, 2020).

It is worth noting that the market approach presupposes the maximum adaptability of the enterprise to the factors of the external environment; however, this is not consistent with the modern paradigm of innovative competitiveness. Consequently, the main source of innovative competitive advantages can be the internal environment, the effective management and proactive development of which allows creating key competencies and accumulating competitive advantages, which allow the enterprise to compete in the market to a superior degree (Dirsehan, 2015; Whalen \& Han, 2018). 
Figure 1. Key parameters and aspects included in the model of innovative competitiveness

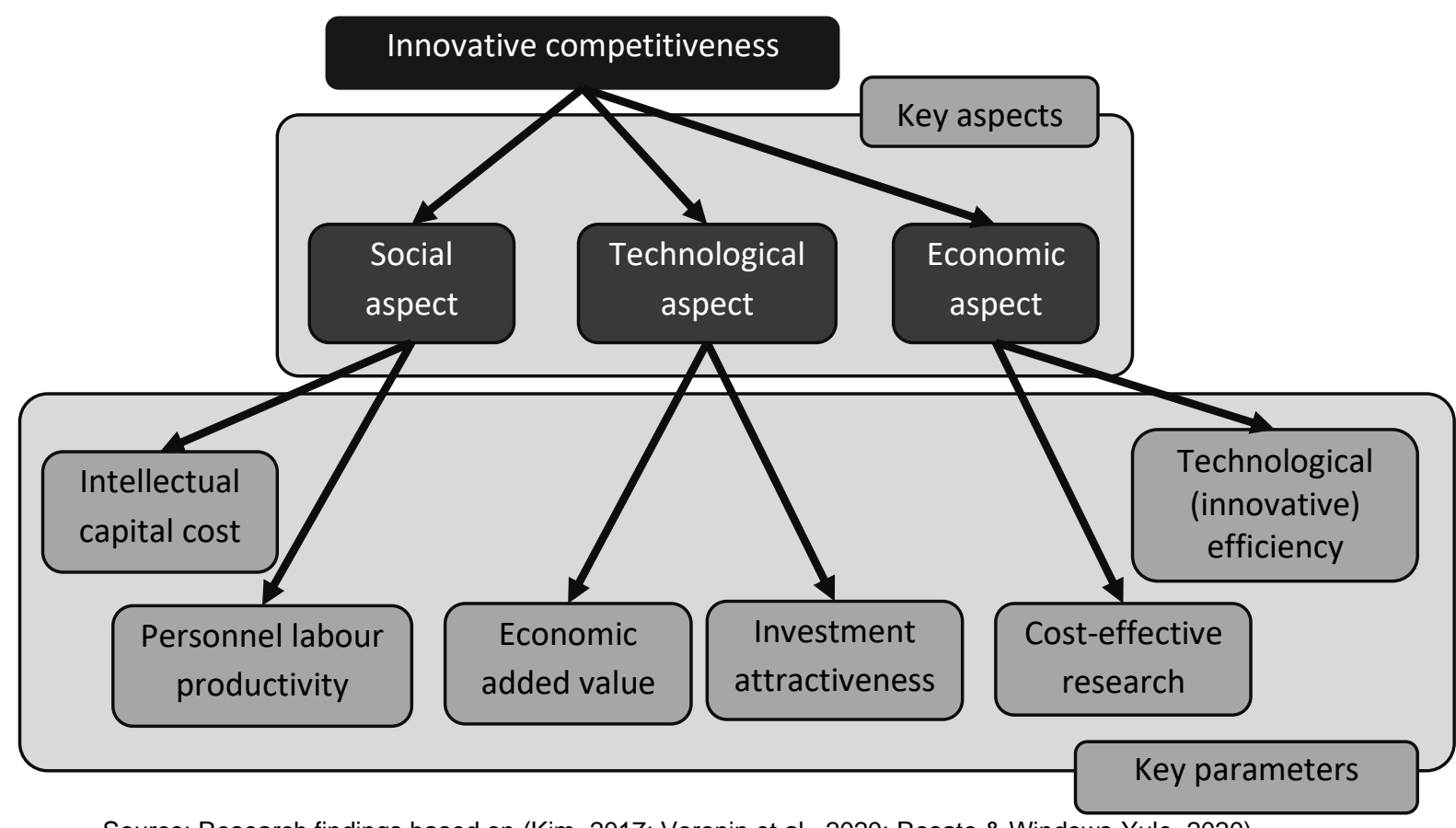

Source: Research findings based on (Kim, 2017; Voronin et al., 2020; Rosato \& Windows-Yule, 2020)

Drivers of intensive, innovative development of an enterprise are incentives that ensure progressive development. They are formed due to the ability of the internal environment of a given subject to use the capabilities of the external environment and transform them into factors of strategically sustainable and competitive development in the long term.

\section{Methodology for modelling the innovative competitiveness of an enterprise, taking into account the changeable nature of investment support.}

The very nature of such a concept as the innovative competitiveness of an enterprise is a multicriteria category that is formed under the influence of several external and internal factors. These factors, on the one hand, generate the necessary conditions and produce the required resources for the development of the innovative activity, and, on the other hand, contribute to the accumulation of new qualities needed for successful competition in the market of the main activity. Accordingly, the process of modelling the innovative competitiveness of an enterprise with a change in investment support is presented in the form of three groups of indicators (socially, economically, technologically oriented).

\subsection{The group of parameters that determine competitiveness in the social aspect (SA).}

Socially oriented indicators are designed to characterise the innovative competitiveness of the enterprise, both in terms of optimising working conditions and in terms of stimulating innovative processes at the enterprise. Besides, socially-oriented indicators make it possible to understand how effectively within the framework of the main activity, processes are carried out to improve and accumulate human and intellectual capital, and also provide an indirect assessment of the ability of management to use cognitive resources.

Increase in intellectual capital, this parameter allows you to assess the ability to capitalise organisational knowledge and subsequently transform it into competitive advantages:

$$
S_{I C}=\frac{M P R_{1}}{M P R_{0}}
$$


where $M P R_{1}, M P R_{0}$ are the market value of research and development carried out by the employees of the enterprise in the current and base periods, respectively.

The parameter of the cost-return of created jobs, the main activity of which is related to innovation processes. This parameter allows you to assess the effectiveness of employees 'innovative activities and the feasibility of investing in the development and stimulation of certain types of employees' innovative activity:

$$
S_{C R W}=\frac{P W_{i}}{C W_{i}}
$$

where $P W_{i}$ is the amount of income received from the $i$-th workplace, $C W_{i}$ is the amount of expenses associated with the maintenance of the $i$-th workplace.

The parameter of the labour activity of employees makes it possible to assess how effective the motivation programs are at the enterprise, as well as indirectly determine the gaps in training programs for personnel:

$$
S_{W A}=\frac{G_{P L}}{G_{D L}} \times k_{a}
$$

where $G_{P L}$ and $G_{D L}$ are, respectively, the growth rate of specific labour productivity associated with innovation processes and the growth rate of unit wages, and $k_{a}$ is the coefficient of a good product (the proportion of non-defective products in the total production volume).

The parameter of the effectiveness of social investments in the field of training and education, allows you to assess the effectiveness of investment in the social sphere and the feasibility of investments in personnel development:

$$
S_{S I}=\frac{G_{P L}}{G_{S I}} \times k_{a}
$$

where $G_{S I}$ is the growth rate of investment in personnel (training, education, instruction, etc.).

\subsection{The group of parameters characterising the competitiveness of an entity in the economic aspect (EA).}

This group of parameters makes it possible to assess the ability of an enterprise to commercialise innovations, in other words, it characterises the value and cost success of the implementation and development of innovative processes at the enterprise. The ability to derive direct economic benefits from innovation, as well as to generate indirect economic benefits, means the presence in the system and structure of management of activities of key competencies and the possession of competitive advantages that constitute competitive potential.

Value-added efficiency parameter. This indicator makes it possible to assess the ability of an enterprise to increase added value through the efficient use of available resources, as well as through the modernisation and improvement of technological processes, and the active implementation of innovative procedures.

$$
E_{A V}=\frac{E V A_{1}}{E V A_{0}}
$$

where $E V A_{1}$ and $E V A_{0}$ - the sum of the created economic value added in the current and base period.

The parameter investment attractiveness is a crucial indicator characterising an enterprise as a significant partner, worthy of investing investment resources. From the point of view of the model being created, this parameter is formed by focusing the enterprise on its innovative advantages, which make it possible to increase the interest of potential investors in investing financial resources: 


$$
E_{I A}=\frac{E I R}{I D}
$$

where EIR is the sum of investment resources attracted from outside, aimed at ensuring competitive development, $I D$ is the investment needs of competitive development not covered by its own resources.

The demand for a product by the market, this parameter makes it possible to show the effectiveness of the ongoing commercialisation of knowledge and innovations in terms of market acceptance of manufactured products, as well as assess the level of demand for them:

$$
E_{M D P}=\frac{V_{1}}{V_{0}} \times\left(1-k_{m}\right)
$$

where $V_{1}$ and $V_{0}$ are the sales volumes of products in the current and base period, $k_{m}$ is the share of product marketing costs in total costs.

The parameter of profitability of intangible assets capitalised research and development. This indicator characterises the ability of these assets, as well as ongoing research and development, to generate profits, as well as provide an opportunity to increase the competitive advantage of the enterprise:

$$
E_{R I A}=\frac{O P}{\sum A C I A}
$$

where $O P$ is the sum of operating income for the current period, $A C I A$ is the average cost of intangible assets, capitalised research and development of the current period.

\subsection{The group of parameters characterising the competitiveness of a subject in the technological aspect (TA).}

Technology-oriented indicators make it possible to assess the ability of an enterprise to effectively use its own and external innovative technologies and solutions to achieve balanced economic growth and strengthen its competitive position in the market (Kwilinski \& Kuzior, 2020).

The parameter of innovative efficiency, in the created model, will determine the ability of the enterprise to benefit from knowledge-intensive investments:

$$
T_{I E}=\frac{D_{R D}}{E_{R D}}
$$

where $D_{R D}$ and $E_{R D}$ - the ratio of income and expenses received through research and development.

The parameter of innovative independence determines the level of self-sufficiency of the enterprise as a critical subject in the field of research and development of a fundamental or applied nature:

$$
T_{I I}=\frac{R D_{S}}{R D_{K}}
$$

where $R D_{S}$ is the total cost of research and development carried out by ourselves, $R D_{K}$ is the total cost of research and development borrowed from third parties.

The parameter of innovation activity determines the ability to intensify the benefits obtained from the ongoing innovation activity, as well as the effect of the implemented innovation:

$$
T_{I A}=\frac{G D_{R D}}{G E_{R D}}
$$


where $G D_{R D}$ and $G E_{R D}$ - the ratio of the growth rate of income and expenses associated with research and development.

The parameter of innovative performance characterises the ability of an enterprise to improve its operational activities by introducing innovative technologies and implementing innovative products, as well as conducting research and development, as well as attracting third-party knowledge:

$$
T_{I P}=\frac{O T}{N T}=k r
$$

where $k r$ is the replacement rate of the number of obsolete technologies (OT) with new technologies (NT) developed or attracted from outside.

A characteristic feature of the enterprise's innovative competitive advantages proposed for the formation of a model is that the key parameters due to which the model is formed are expressed through coefficient indicators and have the same evaluative and analytical interpretation - an increase in any indicator is assessed positively, a decrease in any indicator (or group value) is evaluated negatively.

The calculation of the integrated indicator of the innovative competitiveness of an enterprise with a change in investment support is advisable to be based on the following formula:

$$
E I C=\sqrt[3]{E A_{w e} \times T A_{w t} \times S A_{w a}}
$$

where $E A, T A, S A$ are the total values of the indicators of the economic, technological, social segments of the innovative competitiveness of the enterprise; we, $w t$, ws - weight of the group of indicators of economic, technological and social segments of the enterprise's innovative competitiveness.

It should be noted that the weight of a group of parameters may vary from model to model, depending on expert assessments, but in this work, the weights will be taken in the following values: the social and technological groups of parameters will have a weight value of 0.35 each, since social parameters - reflect the value of human capital as the main generator of innovative activity, on the other hand, technological parameters - reflect the processes of transforming cognitive resources into final products;

The economical group of parameters of the model of the innovative competitiveness of the enterprise will have a weight value of 0.3 , since it is the resultant and directly depends on the social and technological groups.

Thus, in our opinion, it is more correctly to calculate and assess changes in the competitiveness of a particular subject of innovative entrepreneurship, taking into account the dynamics of the weighted average indicator. Respectively:

- a decrease in the integrated weighted average assessment in dynamics is a decrease in competitiveness due to the influence of a combination of internal and external factors (limited ability to master external opportunities with an increasing level of threats);

- an increase in the integrated weighted average assessment is an increase in competitiveness, also due to the influence of a combination of internal and external factors (sufficient ability to master external opportunities with a persisting/acceptable level of threats).

\section{Experiment and analysis of results.}

It should be noted that the basis for the experiment will be an enterprise that is actively engaged in the development and implementation of new technological methods, its activities are closely related to innovation processes, which naturally leads to the innovative activity of both employees and managing managers.

However, a comprehensive analysis of the market environment showed that in the segment controlled by the company, there are potential opportunities for competitive expansion of activities: 
- increased consumer demand for modernised models of manufactured products;

- economic and social transformations have led to an increase in responsible consumption (the transition from consumer hedonism to consumer rationalism);

- at the state level, environmental standards have been tightened, along with this in society, there is an increase in interest in the consumption of environmentally friendly products.

All these factors have created a favourable environment for changing the vector of the enterprise's strategy from the intensification of production to innovative modernisation, both of the leading technologies and related ones (Dzwigol \& Dzwigol-Barosz, 2020).

The company has a full-time staff of 244 people (as of the beginning of 2019) and an annual economic turnover of about $\$ 433$ million. The share of income received from innovation activities in the total volume of economic turnover created by the enterprise is about $39 \%$, the percentage of expenses for innovative activities and the attraction of innovative technologies from outside is about $47 \%$ as of the beginning of 2019, the data is illustrated in Fig. 2.

The key area of the enterprise's activity is the development of new products, technological, organisational and marketing solutions in the b2b field. Also, the company carries out the creation and serial production of high-tech equipment used in the processing and mining industries. 1.

Initial data for modelling the innovative competitiveness of an enterprise are presented in Table

Attention should be paid to two key indicators characterising the volatile nature of the financial support of the enterprise's innovative activities, as well as the volume of attracted investment resources. For clarity, these data are shown in the form of a graph in Fig. 3.

It is noticeable that despite the increasing volumes of attracted investment resources (there is an increase of $12 \%$ in 2019), nevertheless, a significant share of innovative projects remains underfunded, which will be further displayed on the finished model.

Figure 2. The structure of income and expenses in the aspect of conducting innovative activities

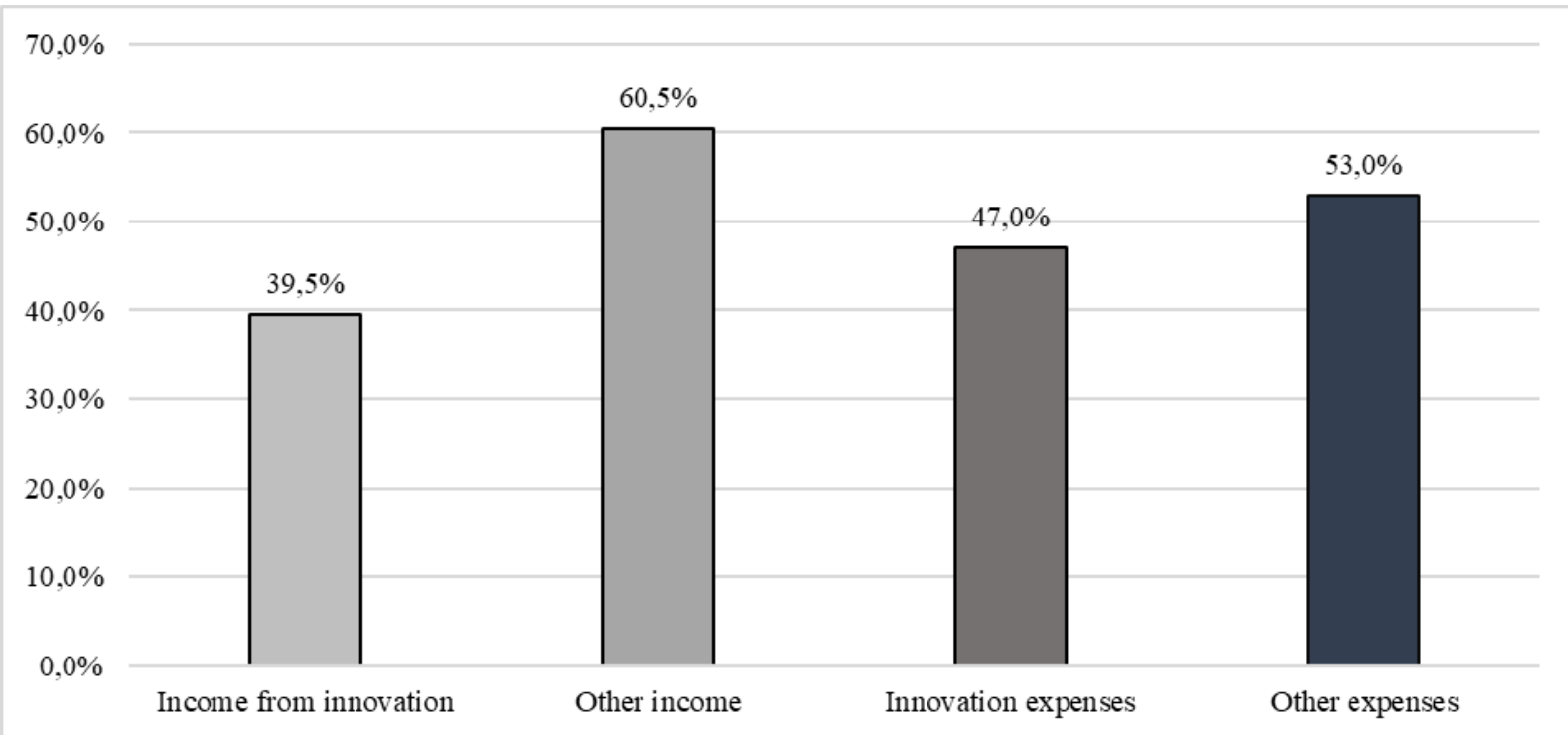

Source: Research findings 
Figure 3. Dynamics of changes in investment support for innovation

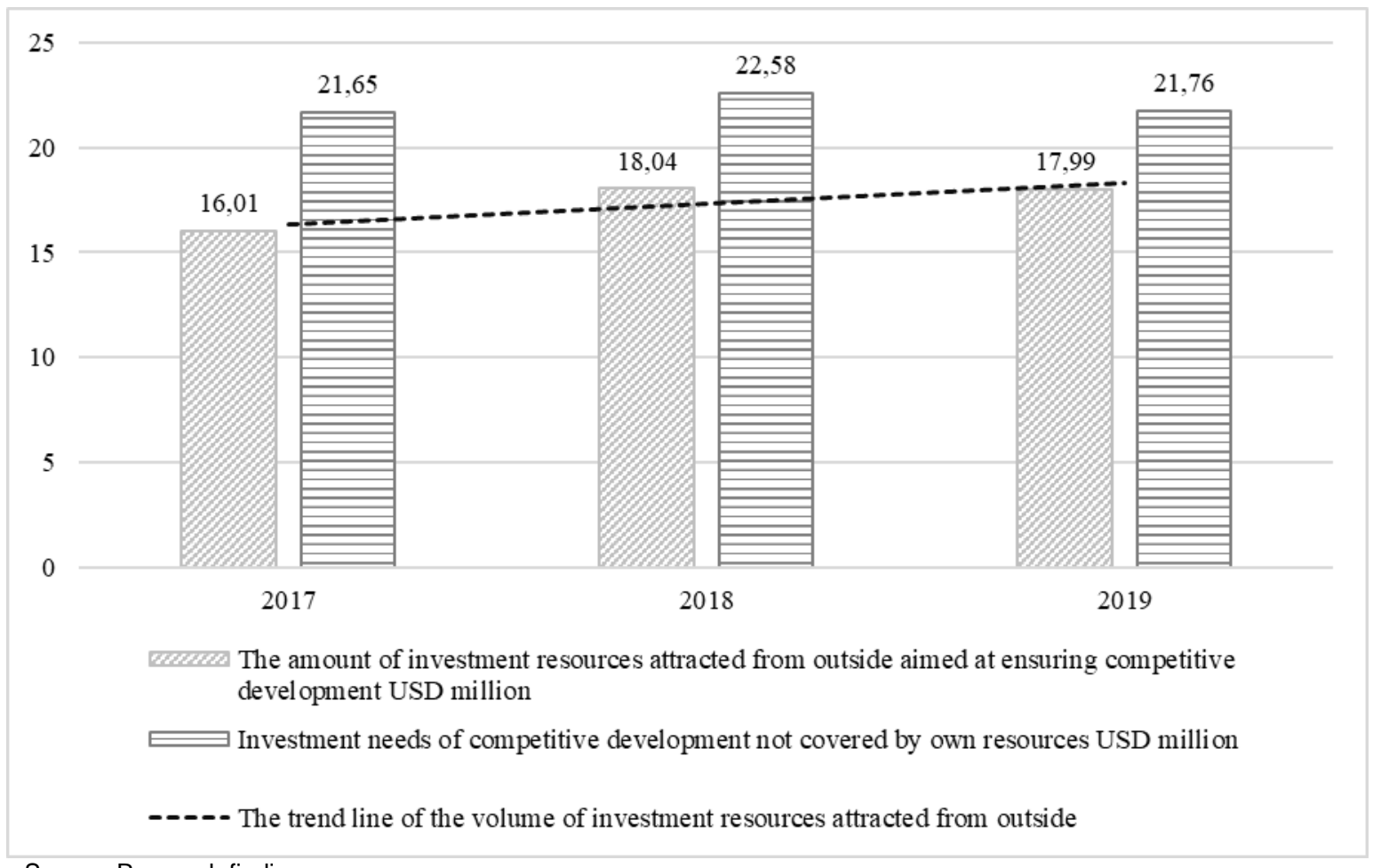

Source: Research findings

Table 1. Initial data for modelling and assessing innovative competitiveness

\begin{tabular}{|c|c|c|c|c|}
\hline Index & $\begin{array}{l}\text { Unit of } \\
\text { measurement }\end{array}$ & 2017 & 2018 & 2019 \\
\hline $\begin{array}{l}\text { The market value of research and development carried } \\
\text { out by employees in the current period }\end{array}$ & USD million & 8,36 & 10,49 & 11,31 \\
\hline $\begin{array}{l}\text { The market value of research and development carried } \\
\text { out by employees in the reference period }\end{array}$ & USD million & 7,51 & 8,96 & 9,39 \\
\hline Income received from the $i$-th workplace & USD million & 4,74 & 4,65 & 5,43 \\
\hline $\begin{array}{l}\text { The amount of expenses associated with the creation } \\
\text { and maintenance }\end{array}$ & USD million & 1,83 & 2,16 & 1,99 \\
\hline The growth rate of specific labour productivity & $\%$ & 3,35 & 4,92 & 5,35 \\
\hline Rate of growth of unit wages & $\%$ & 4,51 & 4,96 & 3,38 \\
\hline $\begin{array}{l}\text { Good product ratio (share of non-defective products in } \\
\text { total production) }\end{array}$ & $\%$ & 0,83 & 1,33 & 1,13 \\
\hline $\begin{array}{l}\text { Growth rates of investments in personnel (training, } \\
\text { development, social protection and support) }\end{array}$ & $\%$ & 3,25 & 4,89 & 4,21 \\
\hline $\begin{array}{l}\text { The amount of economic value-added created in the } \\
\text { current period }\end{array}$ & USD million & 8,96 & 7,92 & 9,21 \\
\hline $\begin{array}{l}\text { The amount of created economic value added in the } \\
\text { reference period }\end{array}$ & USD million & 7,29 & 8,96 & 7,92 \\
\hline $\begin{array}{l}\text { The amount of investment resources attracted from } \\
\text { outside aimed at ensuring competitive development }\end{array}$ & USD million & 16,01 & 18,04 & 17,99 \\
\hline $\begin{array}{l}\text { Investment needs of competitive development not } \\
\text { covered by own resources }\end{array}$ & USD million & 21,65 & 22,58 & 21,76 \\
\hline Sales volumes of products in the current period & USD million & 699,2 & 732,2 & 810,8 \\
\hline Sales volumes of products in the previous (base) period & USD million & 578,93 & 699,2 & 732,2 \\
\hline
\end{tabular}




\begin{tabular}{|c|c|c|c|c|}
\hline Share of product marketing costs in total costs & & 0,11 & 0,13 & 0,15 \\
\hline Operating profit (sales profit) of the current period & USD million & 136,72 & 150,75 & 159,63 \\
\hline $\begin{array}{l}\text { The average cost of intangible assets, capitalised } \\
\text { research and development, the current period }\end{array}$ & USD million & 214,05 & 268,9 & 284,05 \\
\hline Income generated from research and development & USD million & 216,11 & 228,88 & 235,29 \\
\hline Costs incurred as a result of research and development & USD million & 209,7 & 214,21 & 212,37 \\
\hline $\begin{array}{l}\text { The total cost of research and development carried out } \\
\text { independently }\end{array}$ & USD million & 65,39 & 70,86 & 80,11 \\
\hline $\begin{array}{l}\text { The total cost of research and development borrowed } \\
\text { from third parties }\end{array}$ & USD million & 145,31 & 145,15 & 155,45 \\
\hline $\begin{array}{l}\text { Growth rates of income related to the conduct } \\
\text { (attraction) of research and development }\end{array}$ & $\%$ & 6,29 & 5,12 & 10,99 \\
\hline $\begin{array}{l}\text { Growth rates of costs associated with conducting } \\
\text { (attracting) research and development }\end{array}$ & $\%$ & 7,41 & 2,26 & 9,85 \\
\hline Number of obsolete technologies replaced & units & 6 & 8 & 11 \\
\hline $\begin{array}{l}\text { The number of introduced new technologies developed } \\
\text { or attracted from outside }\end{array}$ & units & 9 & 12 & 18 \\
\hline
\end{tabular}

For example, let's show the calculation of the parameter demand for a product by the market in 2018:

$$
E_{M D P}=\frac{V_{1}}{V_{0}} \times\left(1-k_{m}\right)=\left(\frac{732,2}{699,2}\right) *(1-0,13) \approx 0,911
$$

And the calculation of the integrated indicator of the innovative competitiveness of the enterprise in 2017

$$
E I C_{2017}=\sqrt[3]{E A_{w e} \times T A_{w t} \times S A_{w a}}=\sqrt[3]{1,81 \times 1,1 \times 1,05} \approx 0,28
$$

The calculation data for all indicators are summarised in Table 2.

The modelling of the integrated indicator of competitiveness in dynamics over three years allows us to see the trend line of key indicators characterising the effectiveness of the enterprise's implementation of its innovative potential. Although the positive dynamics of growth in all three groups of indicators is noticeable, there are some fluctuations in some of them. It can be concluded that for a more accurate forecast based on the model used, it is desirable to continue observations during a similar period.

At the same time, analysing the data obtained, one can conclude that this market entity has not only accumulated innovative competitive potential, but also sufficiently developed vital competencies that allow to form competitive advantages and, accordingly, increase entrepreneurial rents.

At the same time, in the group of parameters modelling the economic segment of innovative competitiveness, there is a drawdown in the indicator of investment attractiveness (0.74-0.83). There are also questions about the profitability of intangible assets, capitalised research and development (0.64-0.56). The nature of the data on these parameters may indicate that in the long term, the enterprise may experience significant problems with financing its innovative activities, as a consequence, this situation can lead to a potential decrease in innovative competitiveness in the market.

With all this, at the moment, the enterprise has a constant upward dynamics of the integrated indicator of competitiveness throughout the analysed period. 


\section{Conclusions.}

Mathematical modelling of all aspects of innovative competitiveness is a good tool for analysing the parameters of the external and internal environment. The capabilities of the proposed technique are well revealed when used over long periods. The accuracy of the created model directly depends on both the completeness of the initial data and the length of the analysis period. It should be noted that the time ranges of data for analysis can potentially be aggregated to both a quarter and a month. In this case, the results can be used both for experimental variation of possible change strategies and for analysis and forecasting in a real development strategy.

Table 2. Parameters of the model of innovative competitiveness of the enterprise, in dynamics over three years

\begin{tabular}{|c|c|c|c|}
\hline 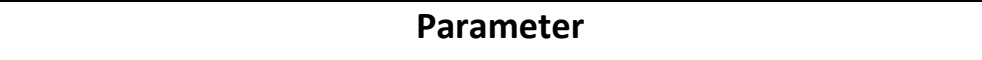 & 2017 & 2018 & 2019 \\
\hline $\begin{array}{l}\text { Group of indicators characterising the competitiveness of the } \\
\text { subject in the social aspect (weighted value) }\end{array}$ & 1,81 & 2,09 & 2,51 \\
\hline Increase in intellectual capital & 1,11 & 1,17 & 1,20 \\
\hline Cost-return of jobs created & 2,59 & 2,15 & 2,73 \\
\hline Labour activity of employees & 0,62 & 1,32 & 1,79 \\
\hline Social investment efficiency & 0,86 & 1,34 & 1,44 \\
\hline $\begin{array}{l}\text { A group of indicators characterising the competitiveness of an } \\
\text { entity in the economic aspect (weighted value) }\end{array}$ & 1,10 & 0,95 & 1,05 \\
\hline Effectiveness of added value creation & 1,23 & 0,88 & 1,16 \\
\hline Investment attractiveness & 0,74 & 0,80 & 0,83 \\
\hline Market demand for the product & 1,07 & 0,91 & 0,94 \\
\hline $\begin{array}{l}\text { Return on intangible assets capitalised research and } \\
\text { development }\end{array}$ & 0,64 & 0,56 & 0,56 \\
\hline $\begin{array}{l}\text { The group of indicators characterising the competitiveness of } \\
\text { the subject in the technological aspect (weighted value) }\end{array}$ & 1,05 & 1,57 & 1,17 \\
\hline Innovative efficiency & 1,03 & 1,07 & 1,11 \\
\hline Innovative independence & 0,45 & 0,49 & 0,52 \\
\hline Innovative activity & 0,85 & 2,27 & 1,12 \\
\hline Innovative performance & 0,67 & 0,67 & 0,61 \\
\hline $\begin{array}{l}\text { Integrated indicator of the competitiveness of the subject of } \\
\text { innovative entrepreneurship }\end{array}$ & 1,28 & 1,46 & 1,45 \\
\hline
\end{tabular}


Innovation, as part of the competitive advantage of an enterprise, is not only a strategically important resource but also an area of potential losses, with volatile financial support. The close relationship between competitiveness, investment attractiveness and innovation is an essential area for economic analysis.

\section{References}

1. Abdollahbeigi, B., \& Salehi, F. (2018). The efficiency of the innovation factors on competitive advantage. Journal of Management and Science, 8 (1), pp. 20-25. DOI: 10.26524/jms.2018.2

2. Akinlo, T., Yinusa, D.O. \& Adejumo, A.V. (2020). Financial development and real sector in subSaharan Africa. Econ Change Restruct, DOI: 10.1007/s10644-020-09283-8

3. Dirsehan, T. (2015). Building Innovative Competitive Advantage in the Minds of Customers. In book: Adoption of Innovation: Balancing Internal and External Stakeholders in the Marketing of Innovation, Springer International Publishing, Editors: Alexander Brem, Eric Viardot, DOI: 10.1007/978-3-319-14523-5_6

4. Dzwigol, H., \& Dzwigol-Barosz, M. (2020). Sustainable Development of the Company on the Basis of Expert Assessment of the Investment Strategy. Academy of Strategic Management Journal, 19(5), 1-7.

5. Garifova, L. (2018). Factors of competitive advantages of the enterprise in regional economy. DOI: 10.26653/1993-4947-2018-87-88-11

6. Kim, B. (2017). Innovation Competition and Strategy. In book: Optimal Control Applications for Operations Strategy, DOI: 10.1007/978-981-10-3599-9_3

7. Koval, V., Mikhno, I., Trokhymets, O., Kustrich, L., \& Vdovenko, N. (2020). Modeling the interaction between environment and the economy considering the impact on ecosystem. E3S Web of Conferences, 166, 13002.

8. Kwilinski, A., \& Kuzior, A. (2020). Cognitive Technologies in the Management and Formation of Directions of the Priority Development of Industrial Enterprises. Management Systems in Production Engineering, 28(2), 133-138. https://doi.org/10.2478/mspe-2020-0020

9. Lee Sheng-Yi, L. (1990). Development of the Financial and Real Sectors. In book: Money and Finance in the Economic Development of Taiwan, DOI: 10.1007/978-1-349-11123-7_7

10.Prokopenko, O. et al. (2020). Communication business processes of industrial enterprises in the conditions of globalisation. International Journal of Management, 11(5), pp. 884-895.

11.Rosato, A., \& Windows-Yule, K. (2020). Influence of key parameters. In book: Segregation in Vibrated Granular Systems, DOI: 10.1016/B978-0-12-814199-1.00018-4

12.Soloveichik, I. (2020). Innovation As A Key Growth Factor And Competitive Advantage Of The Bank. DOI: 10.36807/2411-7269-2020-2-21-110-124

13.Voronin, A., Gunko, O. \& Afanasieva, L. (2020). Dynamics of innovative competition. Innovative technologies and scientific solutions for industries, DOI: 10.30837/2522-9818.2020.12.022

14.Whalen, E. \& Han, J. (2018). The Innovative Competitive Advantage: A Case Study Of Two Pioneering Companies. Journal of Hospitality and Tourism Cases, 6(1), pp. 1-9.

15.Zakharkin, O., Basantsov, I., Shcherbachenko, V., \& Zakharkina, L. (2019). Public-private partnership as an effective tool in R\&D activity. Proceedings of the 33rd International Business Information Management Association Conference, IBIMA 2019: Education Excellence and Innovation Management through Vision 2020, pp. 6674-6678. 